Article

\title{
Brocchia cinerea (Delile) Vis. Essential Oil Antimicrobial Activity and Crop Protection against Cowpea Weevil Callosobruchus maculatus (Fab.)
}

\author{
Abdelkrim Agour ${ }^{1}$, Ibrahim Mssillou ${ }^{1}$, Hamza Mechchate ${ }^{2, *(\mathbb{D}}$, Imane Es-safi ${ }^{2}$ (D) , Aimad Allali ${ }^{3}$ (D), \\ Azeddin El Barnossi ${ }^{4}$, Omkulthom Al Kamaly ${ }^{5, * D}$, Samar Zuhair Alshawwa ${ }^{5} \mathbb{D}_{\text {, Abdelfattah El Moussaoui }}{ }^{(\mathbb{D}}$, \\ Amina Bari ${ }^{4}$, Badiaa Lyoussi ${ }^{1}$ and Elhoussine Derwich ${ }^{1}$
}

Citation: Agour, A.; Mssillou, I.; Mechchate, H.; Es-safi, I.; Allali, A.; Barnossi, A.E.; Al Kamaly, O.; Alshawwa, S.Z.; El Moussaoui, A.; Bari, A.; et al. Brocchia cinerea (Delile) Vis. Essential Oil Antimicrobial Activity and Crop Protection against Cowpea Weevil Callosobruchus maculatus (Fab.). Plants 2022, 11, 583. https://doi.org/10.3390/plants 11050583

Academic Editor: Stefania Garzoli

Received: 17 January 2022

Accepted: 10 February 2022

Published: 22 February 2022

Publisher's Note: MDPI stays neutral with regard to jurisdictional claims in published maps and institutional affiliations.

Copyright: (C) 2022 by the authors. Licensee MDPI, Basel, Switzerland. This article is an open access article distributed under the terms and conditions of the Creative Commons Attribution (CC BY) license (https:// creativecommons.org/licenses/by/ $4.0 /)$.
1 Laboratory of Natural Substances, Pharmacology, Environment, Modeling, Health, and Quality of Life, Faculty of Sciences Dhar El Mahraz, University Sidi Mohamed Ben Abdellah, Fez 30050, Morocco; abdelkrimagour1@gmail.com (A.A.); mssillouibrahim@gmail.com (I.M.); lyoussi@gmail.com (B.L.); elhoussinederwich@yahoo.fr (E.D.)

2 Laboratory of Inorganic Chemistry, Department of Chemistry, University of Helsinki, P.O. Box 55, FI-00014 Helsinki, Finland; Imane.essafi1@usmba.ac.ma

3 Laboratory of Animal and Plant Production, Agro-Industry, Faculty of Sciences, Ibn Tofail University, P.O. Box 133, Kenitra 14000, Morocco; aimad.allali@uit.ac.ma

4 Laboratory of Biotechnology, Environment, Agrifood, and Health, Faculty of Sciences Dhar El Mahraz, University of Sidi Mohamed Ben Abdellah, Fez 30050, Morocco; Azeddin.elbarnossi@usmba.ac.ma (A.E.B.); Abdelfattah.elmoussaoui@usmba.ac.ma (A.E.M.); aminabari3@gmail.com (A.B.)

5 Department of Pharmaceutical Sciences, College of Pharmacy, Princess Nourah Bint Abdulrahman University, P.O. Box 84428, Riyadh 11671, Saudi Arabia; SZAlshawwa@pnu.edu.sa

* Correspondence: Hamza.mechchate@helsinki.fi (H.M.); omalkmali@pnu.edu.sa (O.A.K.)

\begin{abstract}
Antibiotics and synthetic pesticides are now playing a role in the spread of resistant pathogens. They continue to have negative consequences for animal and plant health. The goal of this work is to identify the chemical composition of Brocchia cinerea (Delile) Vis. essential oil (EO) using GC-MS(Gas Chromatography-Mass Spectrometer), evaluate its antimicrobial properties, and investigate its insecticidal and repellent effectiveness against Callosobruchus maculatus (C. maculatus). The GC-MS indicated the presence of 21 chemicals, with thujone $(24.9 \%)$, lyratyl acetate $(24.32 \%)$, camphor $(13.55 \%)$, and 1,8-cineole (10.81\%) being the most prominent. For the antimicrobial assay, the yeast Candida albicans was very sensitive to the EO with a growth inhibition diameter of $(42.33 \mathrm{~mm})$, followed by Staphylococcus aureus ( $31.33 \mathrm{~mm})$. Fusarium oxysporum is the mycelia strain that appeared to be extremely sensitive to the utilized EO (88.44\%) compared to the two species of Aspergillus (A. flavus (48.44\%); A. niger (36.55\%)). The results obtained in the microdilution method show that Pseudomonas aeruginosa was very sensitive to the EO, inhibited by a very low dose $(0.0018 \mathrm{mg} / \mathrm{mL})$. The minimum inhibitory concentration (MIC) results were between 0.0149 and $0.06 \mathrm{mg} / \mathrm{mL}$. B. cinerea EO also demonstrated a potent insecticidal effect and a medium repulsive effect against $C$. maculatus. Thus, the $\mathrm{LC}_{50}$ value in the contact test was $0.61 \mu \mathrm{L} / \mathrm{L}$ of air, lower than that observed in the inhalation test $(0.72 \mu \mathrm{L} / \mathrm{L}$ of air). The present study reveals that $B$. cinerea $\mathrm{EO}$ has the potential to be an antimicrobial and insecticidal agent with a better performance against several pathogenic microorganisms.
\end{abstract}

Keywords: Brocchia cinerea; essential oil; antimicrobial activity; Callosobruchus maculatus; pest control; insecticidal; cowpea

\section{Introduction}

Natural compounds found in herbal extracts and essential oils (EOs), as well as other secondary metabolites of plants, microbes, and enzymes, are gaining huge popularity nowadays, but they are still underutilized [1]. EOs have been shown in several studies to 
control the development of pathogens [2]. The overuse of chemical pesticides has had a negative effect on public health and the environment, and essential oils may be a viable alternative [3]. On the other side, bio-insecticides may be very effective, selective, and have little or no pest resistance and are non-toxic to the environment [4]. Insecticides made from plant EOs may offer safer and less environmentally damaging alternative control options [5]. Brocchia cinerea (Delile) Vis. (B. cinerea) is one of the plant species that belong to the Asteraceae family, known for their richness in essential oils. B. cinerea has traditional uses in the treatment of several diseases and infections related to bacteria [6-8], and due to its good preservative properties, additionally, it is used to filter goat butter [9]. B. cinerea has other biological activities: the powder of this species has an effect on the mycelial growth of Penicillium italicum (43.08\%), the agent responsible for the blue mold of citrus fruits.

Foods that have been stored are susceptible to postharvest loss in quality and quantity due to infestation by a variety of insect species.. The multivoltine pest Callosobruchus maculatus Fab. (Coleoptera: Bruchidae) is causing considerable harm to stored pulses in several tropical nations [10]. Bruchid beetles eat grains and make holes in them, which they utilize to lay eggs. Whole grain is often used, and these holes are often covered and filled with eggs [11]. The C. maculatus alone may cause up to $90 \%$ damage in a period of 3 to 6 months of storage [12]. The control technique is still reliant on fumigation and synthetic pesticides, both of which are hazardous to the environment. Pesticide residues endanger the health of living creatures and pose a serious threat to humans. In order to address rising resistance, the requirement for innovative and efficient bioactive insecticidal compounds has risen [11]. In order to address rising resistance, the requirement for innovative and efficient bioactive insecticidal compounds has risen [13]. Biopesticides derived from essential oils (EOs) seem to be a complementary or alternative method in crop production and integrated pest management aimed at mitigating the adverse effects of conventional synthetic pesticides [14]. On stored product insects, EOs had potentially toxic, repellant, and antifeedent effects [15].

The current study's goal is to figure out the chemical composition by GC-MS of the essential oil of B. cinerea, harvested in the region of Tata (south-east of Morocco), to evaluate its antimicrobial power (against bacterial strains causing nosocomial affections) and antifungal effect (against agents of infection of food), and to carry out a first study on the insecticidal effect of the essential oils of $B$. cinerea against $C$. maculatus, one of most common pest species that attack various types of beans in storage [16].

\section{Results and Discussion}

\subsection{Extraction Yield and Phytochemical Analysis}

The yield of essential oil from $B$. cinerea varies between 0.080 and $0.87 \%$ according to several studies [7]. However, the study of Guaouguaou et al. [17] showed that an extraction that lasted $6 \mathrm{~h}$ gave a yield of $(0.92 \%)$. The yield obtained in our study was $0.39 \%$.

The essential oil's GC-MS analysis revealed the presence of 21 components. The oil was distinguished by a significant concentration of oxygenated monoterpenes. (89.03\%) and low content of hydrocarbon monoterpenes $(10.64 \%)$. These results are in agreement with other studies: Chlif et al. [18] reported that the components identified in the dry aerial parts of $B$. cinerea were oxygenated monoterpenes (56.67\%), monoterpene hydrocarbons $(12.08 \%)$; in a different study, the components identified were oxygenated monoterpenes $(95.40 \%)$ followed by monoterpene hydrocarbons (2.17\%) [19]. In another research, the essential oil of this species was shown to contain oxygenated monoterpenes $(82.3 \%)$ and monoterpene hydrocarbons (14.5\%) [20].

Twenty one constituents representing about $99.97 \%$ of the EO were identified (Figure 1 and Table 1$)$, of which the major components were thujone (24.9\%), lyratyl acetate $(24.32 \%)$, camphor $(13.55 \%)$, and 1,8-cineole (10.81\%). Comparing these results with others reported in several studies (Table 2), it can be seen that the sample studied is distinct by its lyratyl acetate content, which represents almost a quarter of the totality. However, in the majority of cases, thujone or one of its isomers remain the major compounds, with the presence of 
santolina triene, 1,8-cineol, and camphor. The essential oil components of the plant might vary according on environment conditions, soil type and utilized portion, and harvest season.

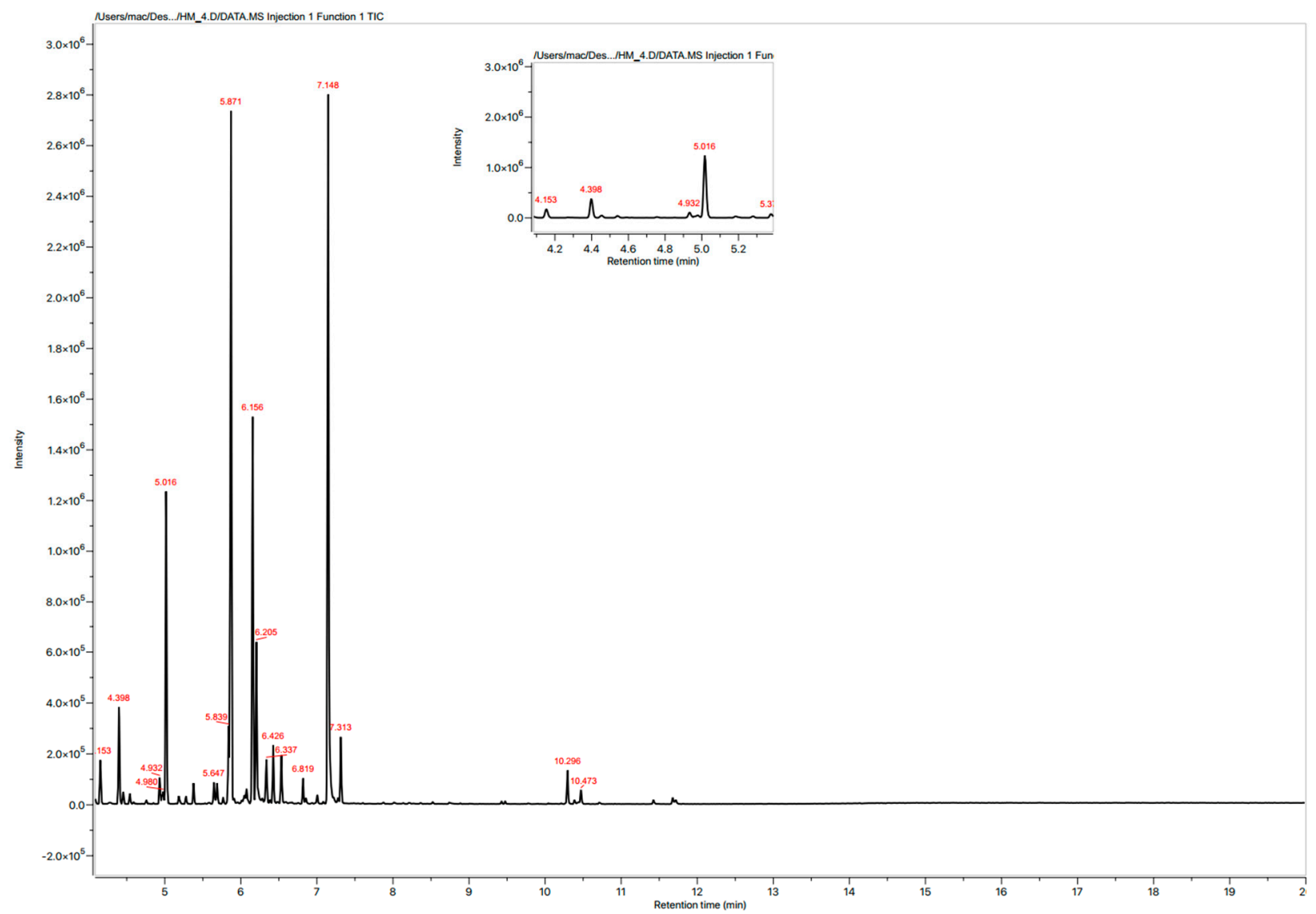

Figure 1. Chromatogram of B. cinerea essential oils GC-MS.

Table 1. Composition of B. cinerea essential oils by GC-MS.

\begin{tabular}{|c|c|c|c|c|c|c|c|c|c|}
\hline $\mathbf{N}$ & RT & Scan & Type & Area & $\begin{array}{c}\text { Total } \\
\text { Height \% }\end{array}$ & $\begin{array}{c}\text { Total } \\
\text { Area \% }\end{array}$ & $\begin{array}{l}\text { Start } \\
\text { Time }\end{array}$ & $\begin{array}{c}\text { End } \\
\text { Time }\end{array}$ & Compound \\
\hline 1 & 4.153 & 17 & $\mathrm{BB}$ & $788,216.000$ & 1.53 & 1.57 & 4.125 & 4.185 & Camphene \\
\hline 2 & 4.398 & 78 & $\mathrm{BB}$ & $1,666,778.000$ & 3.39 & 3.31 & 4.374 & 4.426 & Sabinene \\
\hline 3 & 4.932 & 211 & BV & $451,917.632$ & 0.91 & 0.90 & 4.908 & 4.952 & $p$-cimene \\
\hline 4 & 4.980 & 223 & VV & $285,887.866$ & 0.40 & 0.57 & 4.952 & 4.992 & dl-limonene \\
\hline 5 & 5.016 & 232 & VB & $5,445,985.111$ & 10.94 & 10.81 & 4.992 & 5.044 & 1,8 Cineole \\
\hline 6 & 5.378 & 322 & $\mathrm{BB}$ & $360,219.500$ & 0.73 & 0.72 & 5.357 & 5.406 & Trans-sabinene hydrate \\
\hline 7 & 5.647 & 389 & BV & $399,226.645$ & 0.74 & 0.79 & 5.622 & 5.671 & Isoamyl-2-methyl butyrate \\
\hline 8 & 5.687 & 399 & VB & $361,779.258$ & 0.72 & 0.72 & 5.671 & 5.715 & Cis-sabinenehydrrate \\
\hline 9 & 5.839 & 437 & BV & $1,062,072.472$ & 2.66 & 2.11 & 5.811 & 5.847 & 2,6-Dimethyl-1,3,6-heptatriene \\
\hline 10 & 5.871 & 445 & VB & $12,539,625.462$ & 24.23 & 24.90 & 5.847 & 5.895 & Thujone \\
\hline 11 & 6.076 & 496 & VB & $323,419.762$ & 0.52 & 0.64 & 6.060 & 6.116 & Trans-chysanthemal \\
\hline 12 & 6.156 & 516 & BV & $6,822,674.056$ & 13.55 & 13.55 & 6.128 & 6.181 & (-)Camphor \\
\hline 13 & 6.205 & 528 & VV & $2,748,024.853$ & 5.62 & 5.46 & 6.181 & 6.229 & $p$-Mentha-1(7),8(10)-dien-9-ol \\
\hline 14 & 6.337 & 561 & VB & $852,987.554$ & 1.52 & 1.69 & 6.301 & 6.369 & (-) Borneol \\
\hline 15 & 6.426 & 583 & $\mathrm{BB}$ & $926,375.000$ & 2.02 & 1.84 & 6.401 & 6.454 & 4-Terpineol \\
\hline 16 & 6.534 & 610 & $\mathrm{BB}$ & $811,836.000$ & 1.67 & 1.61 & 6.510 & 6.562 & Alpha-terpineol \\
\hline 17 & 6.819 & 681 & BV & $391,578.433$ & 0.88 & 0.78 & 6.795 & 6.835 & Cis-3-Hexenyl 2-methyl butanoate \\
\hline 18 & 7.148 & 763 & $\mathrm{BB}$ & $12,249,970.000$ & 24.04 & 24.32 & 7.120 & 7.172 & Lyratyl acetate \\
\hline 19 & 7.313 & 804 & VB & $1,059,350.468$ & 2.30 & 2.10 & 7.293 & 7.341 & I-Bornyl acetate \\
\hline 20 & 10.296 & 1547 & $\mathrm{BB}$ & $536,730.000$ & 1.15 & 1.07 & 10.272 & 10.320 & 4-Carene \\
\hline 21 & 10.473 & 1591 & VB & $276,347.888$ & 0.48 & 0.55 & 10.449 & 10.501 & 1,3,6-Octatriene, 3,7-dimethyl \\
\hline
\end{tabular}


Table 2. Majority compounds found in essential oils of B. cinerea.

\begin{tabular}{cc}
\hline Major Compound & Reference \\
\hline Thujone, santolina triene, 1,8-cineol, cis-chrysanthenyl formate. & {$[18]$} \\
Trans-thujone, santalina triene, $\alpha$ - pinene, sabinene, cineole $<1.8>$. & {$[21]$} \\
$\alpha$-thujone. & {$[22]$} \\
Iso-3thujanol; santolina triene; camphor; santolina alcohol. & {$[23]$} \\
Thujone; 3-carene; eucalyptol; santolina triene & {$[24]$} \\
(E)-citral; cis-limonene epoxide; thymol methylether; carvacrol; & {$[19]$} \\
Trans-thujone; cis-verbenyl acetate; 1,8-cineole; santolinatriene & {$[20]$} \\
Thujone; camphor; santolinatriene; eucalyptol; & {$[9]$} \\
\hline
\end{tabular}

\subsection{Antimicrobial Activity}

The findings of the EOs' antibacterial and antifungal activities are provided in Tables 3 and 4, respectively. B. cinerea EO exerted significant inhibitory activity against all microbial strains tested compared to synthetic antibiotics (streptomycin and fluconazole).

Table 3. Antibacterial activity of B. cinerea EO.

\begin{tabular}{ccccc}
\hline & \multicolumn{2}{c}{ Inhibition Zone $(\mathbf{m m})$} & \multicolumn{2}{c}{ MIC $(\mathbf{m g} / \mathbf{m L})$} \\
\cline { 2 - 5 } & EO & Streptomycin & EO & Streptomycin \\
\hline P. aeruginosa & $14.66 \pm 0.57$ & $9 \pm 0.5$ & $0.0018 \pm 0.0008$ & - \\
E. coli & $26.33 \pm 1.52$ & - & $0.0037 \pm 0.001$ & $25 \pm 1.63$ \\
S. aureus & $31.33 \pm 0.57$ & - & $0.03 \pm 0.012$ & $0.62 \pm 0.09$ \\
B. subtils & $25.00 \pm 0.5$ & $10.52 \pm 0.47$ & $0.0375 \pm 0.012$ & $2.81 \pm 0.095$ \\
\hline
\end{tabular}

EO: Essential oil of B. cinerea; (-): Resistant.

Table 4. Antifungal activity of B. cinerea EO.

\begin{tabular}{ccccc}
\hline & \multicolumn{2}{c}{ Zone Inhibition } & \multicolumn{2}{c}{ MIC (mg/mL) } \\
\cline { 2 - 5 } & EO & Fluconazole & EO & Fluconazole \\
\hline C. albicans & $42.33 \pm 2.08(\mathrm{~mm})$ & $21 \pm 1.8(\mathrm{~mm})$ & $0.0168 \pm 0.009$ & $40 \pm 2.29$ \\
\hline A. niger & $36.55 \pm 2.00(\%)$ & $89.75 \pm 0.41$ & $0.03 \pm 0.012$ & $\mathrm{ND}$ \\
\hline A. flavus & $48.44 \pm 2.16(\%)$ & $94.42 \pm 0.92$ & $0.0149 \pm 0.006$ & $\mathrm{ND}$ \\
\hline F. oxysporum & $88.44 \pm 0.19(\%)$ & $91.91 \pm 0.9$ & $0.06 \pm 0.025$ & $\mathrm{ND}$ \\
\hline
\end{tabular}

EO: Essential oils of B. cinerea; ND: Not determined.

The yeast $C$. albicans was very sensitive to the EO with an inhibition diameter of $(42.33 \mathrm{~mm})$, followed by $S$. aureus $(31.33 \mathrm{~mm})$. In addition, the EOs showed lower zones of inhibition against $E$. coli and B. subtills, which were, respectively, $26.33 \mathrm{~mm}$ and $25 \mathrm{~mm}$. However, $P$. aeruginosa showed a little resistance to the essential oil tested compared to the other bacterial species. The mycelia strain, which appears to be very sensitive to the oil used, is F. oxysporum (88.44\%), compared to the two species of Aspergillus (A. flavus $(48.44 \%)$; A. niger $(36.55 \%)$ ).

The results obtained in the microdilution method show that $P$. aeruginosa was very sensitive to $B$. cinerea $\mathrm{EO}$, inhibited by a very low dose $(0.0018 \mathrm{mg} / \mathrm{mL})$. The concentration of $0.0037 \mathrm{mg} / \mathrm{mL}$ was sufficient to stop the growth of E. coli, while B. subtilis appeared to be the least sensitive with an inhibition starting from $(0.037 \mathrm{mg} / \mathrm{mL})$. Similarly, MICs between 0.0149 and $0.06 \mathrm{mg} / \mathrm{mL}$ were sufficient to arrest the growth of mycelia strains. In general, among all the strains studied, the two gram-negative bacteria (E. coli and P. aeruginosa) remained the most sensitive to essential oils extracted from $B$. cinerea. The present study reveals that essential oils extracted from the aerial parts of $B$. cinerea have the potential to be an antimicrobial agent against several pathogenic microorganisms.

Previous studies have been carried out on the antimicrobial effect of the essential oil of $B$. cinerea, or one of its major compounds, against strains belonging to the same genera 
as those examined in this study. Ghouti et al. [22] revealed that B. cinerea oil limits the development of $B$. subtilis by a minimal concentration of (MIC $=0.303 \mathrm{mg} / \mathrm{mL})$. Similarly, the growth of B. subtilis, E. coli, and S. aureus was stopped at 1/500 v/v concentration [23]. In addition, Chouikh [24] found that the strains of E. coli and S. aureus showed great sensitivity to the concentrations $(1 / 1,1 / 2,1 / 4,1 / 8)$ of $\mathrm{EO}$ (flowering period) where the diameter of inhibition ranged between $(21 \mathrm{~mm}$ to $50 \mathrm{~mm}$ ), while $P$. aeruginosa showed stiff resistance with every concentration of essential oil.

The effect of the essential oil of $B$. cinerea also inhibits the growth of mycelial fungi. Reference [25] reported that the oil of this plant inhibits the growth of $A$. niger (50.80\%) at a concentration of $1 / 250 \mathrm{v} / \mathrm{v}$, but complete inhibition of its growth requires a concentration of $1 / 100 v / v$. Similarly, Boussoula et al. [23] showed that oil stops the growth of $A$. niger at $1 / 250 v / v$. It was shown in another study that the activity of essential oils of $B$. cinerea is high against a group of human pathogenic fungi, including Candida albicans, with minimum inhibitory concentrations of 3.2 to $4.7 \mathrm{mg} / \mathrm{mL}$ [26].

According to these observations, it can be speculated that the strong antimicrobial activity exerted by the EOs of $B$. cinerea can be attributed only to the major compounds (thujone, lyratyl acetate, camphor, and 1,8-cineole), which account for about $73.58 \%$ of its total composition, and it could be the result of synergies between the different constituents of the EO [27]. Thujone (major compound) or one of its isomers (A or B) have been reported as molecule inhibiting the growth of several microbial strains including (S. aureus, P. aeruginosa, C. albicans, E. coli, A. niger) [28-31].

The percentage of Lyratyl acetate in the studied essential oils is very significant (24.04\%). Casiglia [32] showed that the essential oils of Anthemis secundiramea, containing (Z)-lyratyl acetate (14.6\%) as a major compound, exhibits significant antibacterial action against a variety of pathogens, with very low MIC values ( $\mu \mathrm{g} / \mathrm{mL}$ ) (B. subtilis 12.5; S. aureus 25; E. coli 50; P. aerogenosa 100; C. albicans 50; F. oxysporum 12.5, and $A$. niger 6.25 ). Other EOs, containing (Z)-lyratyl acetate as the majority compound, inhibited the growth of $A$. flavus (74.4\%) by a concentration of $20 \mu \mathrm{L} /$ petri dish for 6 days) [33].

The antimicrobial activity of camphor depends on its synergistic action with 1,8-cineole or other compounds existing in EOs [34,35]. Silver nanoparticles produced greenly from camphor extract, on the other hand, demonstrated their potential to favorably suppress isolated bacterial pathogens of both American and European foulbrood [36].

1,8-cineole inhibited the growth of $A$. niger (52.3 $\pm 43 \%)$ and F. oxysporum $(72.2 \pm 2.6 \%)$ by a concentration of $0.918 \mathrm{mg} / \mathrm{mL}$. In addition, its presence in the essential oil in large quantities generates a very remarkable antimicrobial power [37]. Wagner et al. [38], showed that the EOs of Lavandula dentata, containing eucalyptol (or 1,8-cineole) (34.33\%), fenchone $(17.78 \%)$, and camphor $(15.75 \%)$, had significant fungicidal action against Cercospora kikuchii, Cercospora sojina, and Septoria glycines plant pathogenic fungi, with diameters of the inhibition zone of 34.00, 29.50, and $22.00 \mathrm{~mm}$ at a concentration of $5 \mu \mathrm{L} /$ disc, respectively.

According to the results of later studies, it is assumed that the strong antimicrobial activity of the $B$. cinerea EOs is strongly due to the presence of lyratyl acetate, 1,8-cineole, and monoterpene alcohols ( $p$-Mentha-1(7),8(10)-dien-9-ol(5.62\%), 4-Terpineol (2.02\%), (-) Borneol (1.52\%); $\alpha$-terpineol (1.67\%)). Indeed, Dorman et al. [39] tested a large number of pure constituents of EOs against 25 different genera of bacteria and showed that thymol is the compound with the broadest spectrum of antibacterial activity followed by carvacrol and $\alpha$-terpineol.

The EO's antibacterial action was thought to include simultaneous cytomembrane breakdown, which resulted in the release of intracellular constituents including protein and $\mathrm{K}^{+}$[40]. As for their mode of action, EOs cause cell wall damage by establishing a membrane potential across the cell wall and disrupting ATP assembly [41]. However, the inhibitory power of the molecules remains inferior to that exerted by EOs containing these molecules as majority compounds or in large quantities [40]; this boosted effect can be explained by the synergic effect of the molecules contained in the EO. 


\subsection{Insecticidal Activity}

Figures 2 and 3 present the results of the action of $B$. cinerea oils tested by inhalation and by contact on the mortality of $C$. maculatus. Indeed, at the lowest concentration $(1 \mu \mathrm{L} / \mathrm{L}$ of air) tested by inhalation, and after $24 \mathrm{~h}$ of exposure, the essential oils of $B$. cinerea cause a mortality of $63.33 \pm 15.28 \%$ of the adults of $C$. maculatus, while the toxicity by contact induces $80 \pm 10 \%$ mortality. At the highest concentration $(20 \mu \mathrm{L} / 100 \mathrm{~g})$, B. cinerea EOs showed significantly higher action compared to the control and caused $100 \%$ mortality in both tests, respectively. Statistical analysis (Table 5) shows that the LC50 value in the inhalation test $(0.72 \mu \mathrm{L} / \mathrm{L}$ of air $)$ is higher than that observed in the contact test $(0.61 \mu \mathrm{L} / \mathrm{L}$ of air).

Table 6 shows that the $\mathrm{EO}$ of $B$. cinerea $(\mathrm{EOBC})$ caused a significant reduction in fecundity. Thus, the application of the low concentration $(1 \mu \mathrm{L} / 100 \mathrm{~g})$ resulted in an oviposition reduction rate of $95.98 \%$ when compared to the control group. When applying a concentration of $(20 \mu \mathrm{L} / 100 \mathrm{~g})$, the rate of egg laying reduction is $100 \%$. The number of eggs laid per female C. maculatus in the control jar is $207.33 \pm 12.5$. For emergence, a significant reduction rate of $91.34 \%$ was observed using $(20 \mu \mathrm{L} / 100 \mathrm{~g})$.

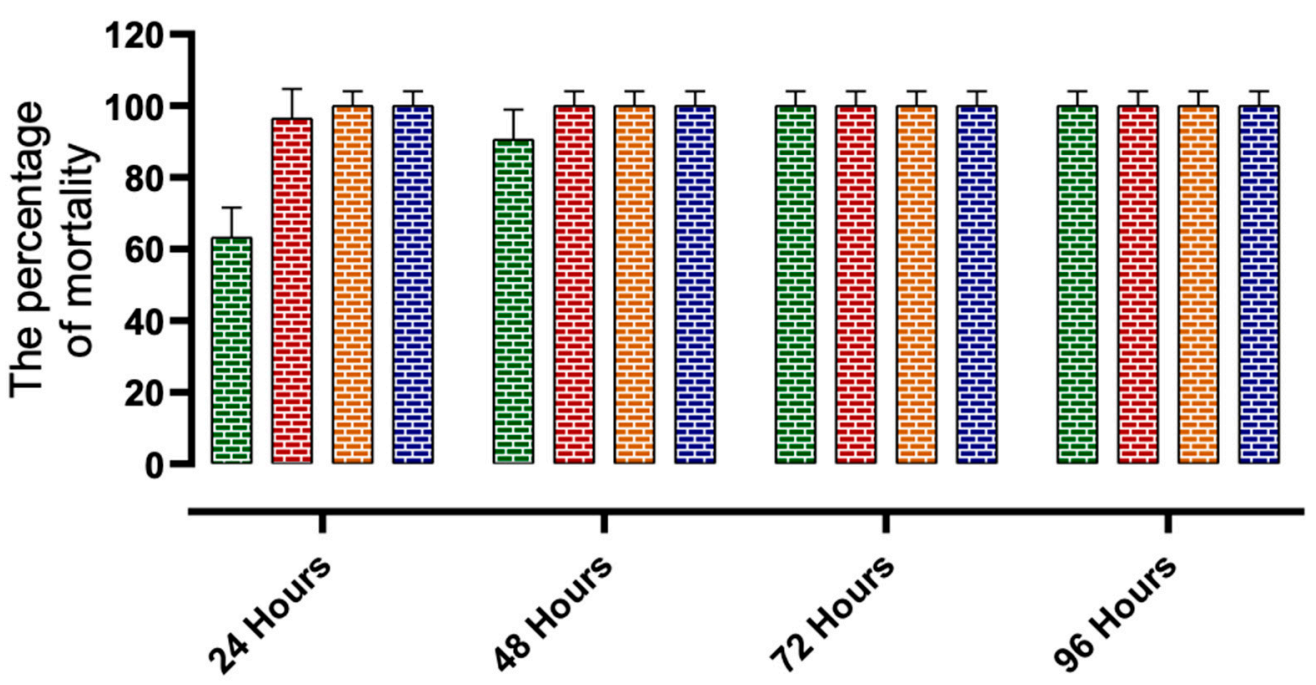

EOBC $1 \mu \mathrm{L} / 100 \mathrm{~g}$

垔 $\mathrm{EOBC} 5 \mu \mathrm{L} / 100 \mathrm{~g}$

플

EOBC $20 \mu \mathrm{L} / 100 \mathrm{~g}$

Figure 2. The effects of inhaling essential oil of B. cinerea (EOBC) on the mortality of adults of C. maculatus.

EOBC: Essential oil of B. cinerea

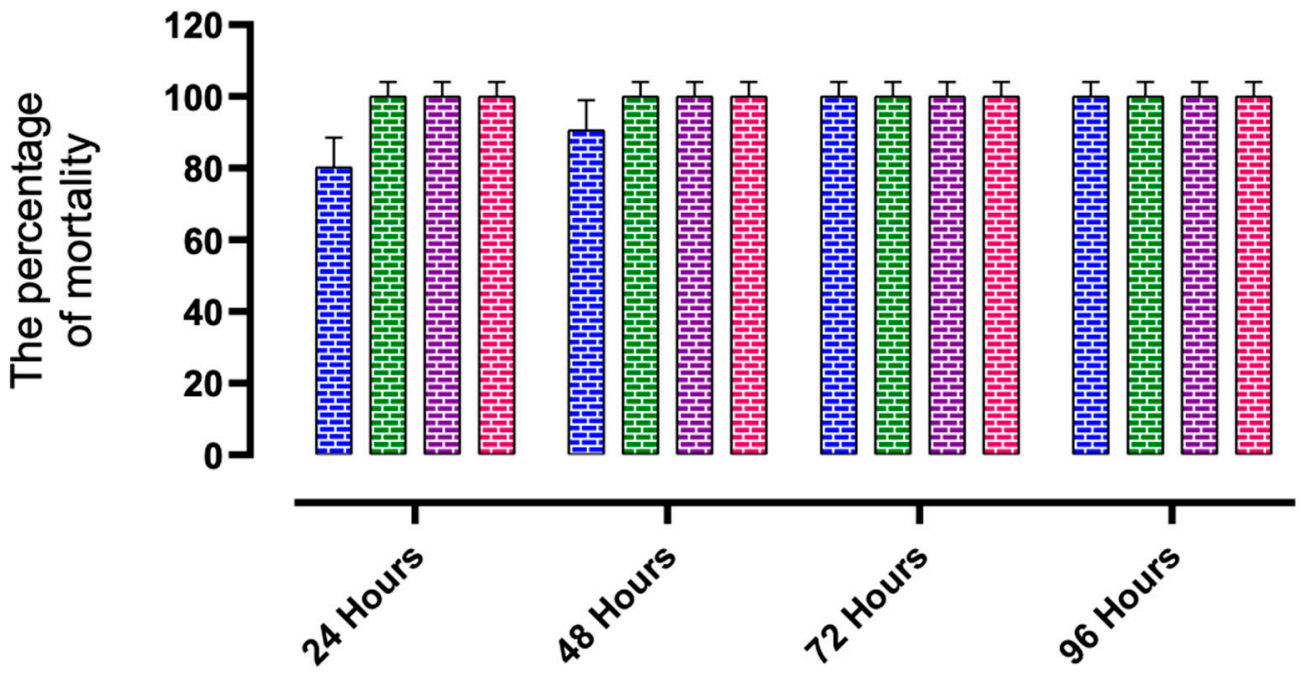

EOBC $1 \mu \mathrm{L} / 100 \mathrm{~g}$

䂑 EOBC $5 \mu \mathrm{L} / 100 \mathrm{~g}$

EOBC $10 \mu \mathrm{L} / 100 \mathrm{~g}$

EOBC $20 \mu \mathrm{L} / 100 \mathrm{~g}$

Figure 3. The effects of $B$. cinerea essential oil on the mortality of adults of $C$. maculatus by contact. 
EOBC: Essential oil of B. cinerea

Table 5. Lethal concentration values of B. cinerea EOs tested on C. maculatus.

\begin{tabular}{lccccc}
\hline Treatment & DF & $\begin{array}{c}\text { Slope } \\
( \pm \text { SE) }\end{array}$ & LC $_{\mathbf{5 0}}$ (CI95\%) & CL 95 (CI95\%) & $\chi^{2}$ \\
\hline Inhalation & 2 & $2.32 \pm 0.34$ & $0.72(0.5-0.93)$ & $3.67(2.78-5.7)$ & 0.71 \\
By contact & 2 & $3.99 \pm 3.21$ & $0.61 *$ & $1.59 *$ & 0.14 \\
\hline
\end{tabular}

$\mathrm{DF}=$ degree of freedom; $\mathrm{SE}=$ standard error; $\mathrm{CI}=$ confidence interval; $\chi^{2}=$ Chi-deux. ${ }^{*}$ Confidence intervals are too wide; they do not lend themselves to calculation.

Table 6. Effects of B. cinerea EOs on fecundity and adult emergence of C. maculatus.

\begin{tabular}{ccc}
\hline Dosage $(\mu \mathrm{m} / \mathrm{L})$ & Egg Laying Reduction Rate (\%) & Adult Inhibition Rate (\% IR) \\
\hline Control & $0^{\mathrm{a}}$ & $0^{\mathrm{a}}$ \\
1 & $95.9 \mathrm{~b}^{\mathrm{a}}$ & $100^{\mathrm{b}}$ \\
5 & $98.87^{\mathrm{c}}$ & $100^{\mathrm{b}}$ \\
10 & $100^{\mathrm{c}}$ & $100^{\mathrm{b}}$ \\
20 & $100^{\mathrm{c}}$ & $100^{\mathrm{b}}$ \\
\hline
\end{tabular}

All experiments were repeated 3 times. P: significant differences determined by one-way ANOVA. In each column of the table, values followed by the same letter are not significantly different from each other at $p<0.05$ (LSD Test).

\subsection{Cowpea Weevil Insecticidal Activity}

The results presented in Table 7 show that the B. cinerea EOs present a medium repulsive effect on the adults of $C$. maculatus with an average repulsion of $38.33 \pm 11.38 \%$, classifying them, respectively, in class III according to the classification of McDonald et al. [42].

Table 7. Repellent activity of B. cinerea EOs against insects of C. maculatus.

\begin{tabular}{ccc}
\hline & Dose $\left(\mu \mathrm{L} / \mathrm{cm}^{2}\right)$ & Repulsion Rate $( \pm$ SD) \\
\hline C. maculatus & 0.016 & $26.67 \pm 11.54^{\mathrm{a}}$ \\
& 0.079 & $33.33 \pm 11.54^{\mathrm{ab}}$ \\
& 0.157 & $40 \pm 20^{\mathrm{bc}}$ \\
\hline Average PR $(\% \pm \mathrm{ET})$ & 0.315 & $53.33 \pm 23.09^{\mathrm{c}}$ \\
\hline Repulsion class & - & $38.33 \pm 11.38$ \\
\hline
\end{tabular}

All experiments were repeated 3 times. P: significant differences determined by one-way ANOVA. Values followed by the same letter do not differ significantly from each other at $p<0.05$ (LSD test).

Using the contact and inhalation test, the total mortality was very important; the $\mathrm{LC}_{50}$ was 0.62 and $0.73 \mu \mathrm{L} / \mathrm{L}$, respectively. In the bibliography, several works have been conducted on the insecticidal activity of EOs or certain volatile compounds against $C$. maculatus, all using several protocols, inhalation, fumigation, contact, and repulsion.

Some EOs contain majority compounds resembling those obtained in the B. cinerea EOs used in the present study. Using the fumigation technique, the EOs of Rosmarinus officinalis L., composed mainly of $\alpha$-pinene (22.64\%), camphor (21.84\%), 1,8-cineole (21.53\%), and camphene $(9.18 \%)$, show an insecticidal effect against $C$. maculatus with an $\mathrm{LC}_{50}=15.69 \mu \mathrm{L} / \mathrm{L}$ air [43]. In a recent study [44], it was reported that the EOs of Salvia officinalis, containing $\alpha$-thuyone (24.27\%), camphor (18.10\%), $1-8$ cineol (14.38\%), and $\beta$ thujone $(7.38 \%)$ as major components, were toxic against $C$. maculatus, while batches treated with $16 \mu \mathrm{L} / \mathrm{L}$ of EOs air resulted in $33.5 \%$ of eggs hatched, while $24 \%$ evolved into larvae and $19.5 \%$ was the number of emergences. It was also shown previously that EOs isolated from Artemisia herba-alba had an $\mathrm{LD}_{50}$ of $11.670 \%$ against the insect tested using the contact test, the major compounds of these oils were chrysanthenone $(31.40 \%)$, camphor $(15.97 \%)$, alpha-thuyone $(14.90 \%)$, the 1,8-cineole (4.57\%), and camphene (3.95\%) [45]. 
EOs containing high amounts of certain volatile compounds have been used to control the insect pest C. maculatus. The oil extracted from E. caryophyllus $(74.31 \%$ of eugenol), has an $\mathrm{LC}_{50}$ value of $1.27 \mu \mathrm{L} / 20 \mathrm{~g}$ obtained by contact test, and an $\mathrm{LC}_{50}$ of $20.27 \mu \mathrm{L} / \mathrm{L}$ air obtained by fumigation test [46]. Similarly, the EOs of Syzygium aromaticum L. (87.4\% of eugenol) and Cinnamomum zeylanicum L. (73.1\% of eugenol), respectively, have an $\mathrm{LD}_{50}$ of 78.2 and $131 \mu \mathrm{L} / \mathrm{Kg}$ [47]. In contrast, the use of EOs of I. verum (88.85\% of E-anethole) against $C$. maculatus showed an $\mathrm{LC}_{50}=$ of $9.62 \mu \mathrm{L} / 20 \mathrm{~g}$ by contact test and an $\mathrm{LC}_{50}$ of $22.36 \mu \mathrm{L} / \mathrm{L}$ of air by fumigation test [46].

Previous studies have also reported the insecticidal effect of a few molecules against C. maculatus. The fumigant effect of $\alpha$-bisabolol on C. maculatus oviposition was five eggs at a concentration of $\mathrm{LC}_{50}=2.47 \mu \mathrm{L} \mathrm{L}^{-1}$ compared to 79.25 eggs at hexane application [48], while the use of citral (geranial +Neral) at a concentration of $90 \mu \mathrm{g} / \mathrm{mL}$ leads to a mortality of $(30.00 \%)$, oviposition (55.71\%), and emergence(1.51\%) [49].

\section{Materials and Methods}

\subsection{Plant Material}

Aerial portions of $B$. cinerea were gathered near the town of Akka in Tata province during the second week of February 2021 (south-eastern Morocco). A botanist at the Sidi Mohamed Ben Abdellah University in Fez, Morocco, identified the plant. The laboratory of Natural Substances, Pharmacology, Environment, Modeling, Health \& Quality of Life at the Faculty of Sciences Fez submitted a voucher sample (BC0019220211) at the herbarium.

\subsection{Extraction of Essential Oils}

The Clevenger hydrodistillation equipment is used to extract essential oils. For a total of $200 \mathrm{~g}$ of pre-dried aerial parts, together with $750 \mathrm{~mL}$ of water, the combination is placed in a 2-L flask and allowed to boil for three hours. Temperature was -4 degrees Celsius for the essential oils storage.

\subsection{Analysis of the Essential Oil by GC-MS}

After examining the spectrum data and retention indices of the eluted compounds, the constituents in the essential oil were identified using gas chromatography-mass spectrometry(GC/MS).The coupling was carried out using a device (GC-MS), MS of the Agilent Technologies 5973 type Brand Agilent Technologies Model 5973 with an Agilent column 19091S-433 HP-5MS, $30 \mathrm{~m}$ long, $0.25 \mathrm{~mm}$ inside diameter, and $0.25 \mu \mathrm{m}$ film thickness of the stationary phase

Helium was employed as the carrier in the experiment, with a pressure range (psi) of $0.9 \mathrm{~mL} / \mathrm{s}$. The temperatures of the injector and detector were adjusted at $250{ }^{\circ} \mathrm{C}$ and $260{ }^{\circ} \mathrm{C}$, respectively. The oven temperature was set between 60 and 300 degrees Celsius at a rate of 10 degrees Celsius per minute, and then kept at 300 degrees Celsius for 20 min.

\subsection{Evaluation of Antimicrobial Activity}

\subsubsection{Tested Strains}

The antimicrobial activity of essential oils of $B$. cinerea was evaluated against 4 bacterial strains (E. coli (ATB: 97), B. subtilis, S. aureus, and P. aeruginosa) and 4 fungal strains (C. albicans ATCC 10231, A. flavus, A. niger, and F. oxysporum) which were provided, respectively, from the Laboratory of Bacteriology at the Hassan II University Hospital Center in Fez, Morocco, and the Biotechnology, Environment, Agri-Food and Health Laboratory, har El Mahraz Faculty of Sciences, Sidi Mohammed University Ben Abdellah, Fez, Morocco.

\subsubsection{Agar Diffusion Method}

Evaluation of antibacterial and antifungal activity of B. cinerea essential oils were performed by agar diffusion method [50]. The four bacterial strains were grown in NB (nutrient broth) and MEA (malt extract agar) media on petri plates (C. albicans and inoculated with A. niger, A. flavus, and F. oxysporum). The inoculated medium were covered with Wattman 
paper discs (6 mm in diameter), which were saturated with $20 \mu \mathrm{L}$ of $B$. cinerea essential oils. [51]. The inoculated Petri dishes were incubated at $30{ }^{\circ} \mathrm{C}$ and $37{ }^{\circ} \mathrm{C}$ in the dark for fungal and bacterial strains, respectively. Inhibition diameter and percent inhibition were determined after $24 \mathrm{~h}$ for the 4 bacterial strains and $48 \mathrm{~h}$ for C. albicans and after 7 days of incubation for A. niger, A. flavus, and F. oxysporum [51,52].

\subsubsection{Determination of the Minimum Inhibitory Concentration (MIC)}

The determination of the MIC of $B$. cinerea $\mathrm{EO}$ against the 4 bacterial strains $(E$. coli (ATB:97) BGM; S. aureus, B. subtilis, and P. aeruginosa) and the 4 fungal strains (F. oxysporum, A. niger, C. albicans and A. flavus) was carried out by using the microdilution method in accordance with the method described by [53]. Microplates were prepared under aseptic conditions, each sterile 96-well microplate was labelled, then a volume of $100 \mu \mathrm{L}$ of test EO in $10 \%(v / v)$ DMSO was pipetted into the first row of the plate, into all other wells, $50 \mu \mathrm{L}$ of sterile NB for bacterial strains and $50 \mu \mathrm{L}$ of sterile ME (malt extract) for fungal strains were added, serial dilutions were made using a multichannel pipette, and finally $30 \mu \mathrm{L}$ of microbial suspension of each strain was added to each well. The incubation times were: $24 \mathrm{~h}$ for bacteria; $48 \mathrm{~h}$ for C. albicans; 7 days for fungi at $37{ }^{\circ} \mathrm{C}$ and $30{ }^{\circ} \mathrm{C}$, respectively $[53,54]$. The $\mathrm{MIC}$ end point is determined by direct observation of growth in the wells and by using the colorimetric method using 2,3,5-triphenyltetrazolium chloride (TTC) $0.2 \%(w / v))[54,55]$. The evaluation of MIC, antibacterial, and antifungal activity by the Agar diffusion method, was performed in three repetitions.

\subsection{Insecticidal Activity against C. maculatus}

In this investigation, the species C. maculatus was investigated, which was isolated from a stock of chickpea (Cicer arietinum) from the Fez area. It was maintained by mass rearing carried out in glass jars of different sizes, placed in a high regulated photoperiod of $10 \mathrm{~h}$ of darkness and $14 \mathrm{~h}$ in light, a temperature of $25^{\circ} \mathrm{C}$ and a relative humidity of saturation of $65 \pm 5 \%$.

\subsubsection{Contact Toxicity}

In this assay, $100 \mathrm{~g}$ of seeds were infested with 5 pairs ( 5 male and 5 female individuals) of insects for $0-48 \mathrm{~h}$, packed in sealed plastic containers with lids and covered with a smooth, transparent cloth. The EO were added to the seeds by automatic pipette and shaken manually for $2 \mathrm{~min}$. The mortality of adults was evaluated after 1 day of confinement [56].

A treatment with concentration $(1,5,10,20 \mu \mathrm{L} / 100 \mathrm{~g})$ was performed. Controls for each trial, containing $100 \mathrm{~g}$ of seeds (without essential oil), were also housed with 5 pairs of insects. Eggs deposited in the chickpea seeds were counted at 12 days and emerged insects were counted regularly at 28 days after confinement.

Abbott's formula is used to correct for the observed mortality rate

$$
\mathrm{M}=100 \times \frac{\mathrm{A}-\mathrm{B}}{100-\mathrm{B}}
$$

where $\mathrm{M}=$ percent corrected mortality; $\mathrm{A}=$ observed mortality in the tested group, and $\mathrm{B}=$ observed mortality in the control group.

The percent reduction in eggs and adults at each oil concentration was calculated relative to the control using the following formula

$$
\mathrm{O}=\frac{\mathrm{A}-\mathrm{B}}{\mathrm{A}} \times 100
$$

where $\mathrm{O}=$ Oviposition (or reduction of emerged insects); $\mathrm{A}=$ eggs number (or insects hatched in the control group), and $\mathrm{B}=$ eggs number (or insects hatched in the group given the EO treatment). 


\subsubsection{Test of the Toxicity by Inhalation}

Small cotton masses were hung in glass jars $(1 \mathrm{~L})$ by a thread linked to the inside lid. Concentrations of $1 \mu \mathrm{L}, 5 \mu \mathrm{L}, 10$, and $20 \mu \mathrm{L} / 1 \mathrm{~L}$ of air of $B$. cinerea oil were deposited in the cotton. Ten individuals of $C$. maculatus (male and female) with ages between 0 and $48 \mathrm{~h}$ were placed in each jar with a tightly sealed lid. Three duplicates of each dosage were carried out. A control sample was used to make the comparison (cotton without test solutions).

The observed mortality rate is corrected by the same formula used in the contact toxicity test [57].

\subsubsection{Test of Repulsion}

The repellant effect of $B$. cinerea $\mathrm{EO}$ was tested on filter paper using the preferential area technique outlined by [42]. Thus, filter paper discs $(9 \mathrm{~cm}$ diameter) used for this purpose were cut into two equal halves each having $31.80 \mathrm{~cm}^{2}$ of surface. On one of the two halves a volume of $0.5 \mathrm{~mL}$ of each of the essential oil solutions prepared in acetone with different doses $\left(0.016,0.079,0.157\right.$, and $0.315 \mu \mathrm{L} / \mathrm{cm}^{2}$ per disk). Only $0.5 \mathrm{~mL}$ of acetone was given to the other half. The number of bruchids on the half of the disk treated with essential oil was compared to the number on the untreated half after 30 minutes.

For the calculation of the percentage of repulsion (PR), the following formula was used [58].

$$
\mathrm{R}=\frac{\mathrm{A}-\mathrm{B}}{\mathrm{A}+\mathrm{B}} \times 100
$$

$\mathrm{R}=$ repulsion $(\%)$.

$\mathrm{A}=$ Insects in the control area.

$\mathrm{B}=$ Insects in the treatment area.

\subsection{The Analysis of the Data}

The death rate of C. maculatus was calculated using the formula of [57]. Repeated measures analysis of variance using percent mortality by toxicity was calculated for $24 \mathrm{~h}$, $48 \mathrm{~h}, 72 \mathrm{~h}$, and $96 \mathrm{~h}$. $\mathrm{LC}_{50}$ concentrations were determined using the probit method [59] using "IBM SPSS Program Version 21" software.

\section{Conclusions}

Based on the obtained results, it was confirmed that the essential oils of $B$. cinerea can be used as biopesticides in the integrated management of $C$. maculatus, and it can also be used as antimicrobial alternatives to conventional antibiotics in the control of resistant strains (Fungi and bacteria). This study confirms also that the use of natural products to solve current problems is an effective and safe way to replace antibiotics and pesticides, which number of studies are providing alerts as to their upcoming problems. Further research is needed to better standardize the perfect dosage of EOs to be used for a wide range of applications.

Author Contributions: Conceptualization, A.A. (Abdelkrim Agour) and E.D.; methodology, I.M., A.A. (Aimad Allali) and A.E.B.; formal analysis, H.M. and I.E.-s.; investigation, A.A. (Abdelkrim Agour) and A.E.M.; data curation, H.M.; writing-original draft preparation, A.A. (Abdelkrim Agour) and H.M.; writing-review and editing, O.A.K., S.Z.A. and A.B.; supervision, B.L. and E.D. All authors have read and agreed to the published version of the manuscript.

Funding: This study was funded by Princess Nourah bint Abdulrahman University Researchers Supporting Project number (PNURSP2022R165), Princess Nourah bint Abdulrahman University, Riyadh, Saudi Arabia.

Institutional Review Board Statement: Not applicable.

Informed Consent Statement: Not applicable.

Data Availability Statement: Data are available upon request. 
Acknowledgments: The authors extend their appreciation to Princess Nourah Bint Abdulrahman University Researchers Supporting Project number (PNURSP2022R165), Princess Nourah bint Abdulrahman University, Riyadh, Saudi Arabia. Open access funding provided by University of Helsinki.

Conflicts of Interest: The authors declare no conflict of interest.

\section{References}

1. $\quad$ El-Saber Batiha, G.; Hussein, D.E.; Algammal, A.M.; George, T.T.; Jeandet, P.; Al-Snafi, A.E.; Tiwari, A.; Pagnossa, J.P.; Lima, C.M.; Thorat, N.D.; et al. Application of Natural Antimicrobials in Food Preservation: Recent Views. Food Control 2021, $126,108066$. [CrossRef]

2. Akromah, Z.N.; Jayanegara, A. Meta-Analysis of Essential Oil Effectiveness against Phythopathogen in Forest Plant Nurseries. IOP Conf. Ser. Earth Environ. Sci. 2021, 667, 012005. [CrossRef]

3. Xie, F.; Rizvi, S.A.H.; Zeng, X.; Feng, X.; Syed, A.H.R.; Xinnian, Z. Fumigant Toxicity and Biochemical Properties of $(\alpha+\beta)$ Thujone and 1,8-Cineole Derived from Seriphidium Brevifolium Volatile Oil against the Red Imported Fire Ant Solenopsis Invicta (Hymenoptera: Formicidae). Rev. Bras. Farm. 2019, 29, 720-727. [CrossRef]

4. Tozlu, E.; Cakir, A.; Kordali, S.; Tozlu, G.; Ozer, H.; Akcin, T.A. Chemical Compositions and Insecticidal Effects of Essential Oils Isolated from Achillea Gypsicola, Satureja Hortensis, Origanum Acutidens and Hypericum Scabrum against Broadbean Weevil (Bruchus Dentipes). Sci. Hortic. 2011, 130, 9-17. [CrossRef]

5. Zimmermann, R.C.; Aragão, C.E.d.C.; de Araújo, P.J.P.; Benatto, A.; Chaaban, A.; Martins, C.E.N.; Amaral, W.D.; Cipriano, R.R.; Zawadneak, M.A. Insecticide Activity and Toxicity of Essential Oils against Two Stored-Product Insects. Crop Prot. 2021, 144, 105575. [CrossRef]

6. Idm'Hand, E.; Msanda, F.; Cherifi, K. Ethnobotanical Study and Biodiversity of Medicinal Plants Used in the Tarfaya Province, Morocco. Acta Ecol. Sin. 2020, 40, 134-144. [CrossRef]

7. Lakhdar, M. Traditional Uses, Phytochemistry and Biological Activities of Cotula Cinerea Del: A Review. Trop. J. Pharm. Res. 2018, 17, 365. [CrossRef]

8. Telli, A.; Esnault, M.-A.; Khelil, A.O.E.H. An Ethnopharmacological Survey of Plants Used in Traditional Diabetes Treatment in South-Eastern Algeria (Ouargla Province). J. Arid Environ. 2016, 127, 82-92. [CrossRef]

9. Bouziane, M.; Badjah-Hadj-Ahmed, Y.; Hadj-Mahammed, M. Chemical Composition of the Essential Oil of Brocchia Cinerea Grown in South Eastern of Algeria. Asian J. Chem. 2013, 25, 3917-3921. [CrossRef]

10. Bibi, R. Insecticidal Potential of Botanicals from Red Seaweeds against Stored Grain Pests, Rice Weevil (Sitophilus oryzae L.) and Cowpea Weevil (Callosobruchus maculatus Fab.). Pak. J. Zool. 2021, 1-8. [CrossRef]

11. González, J.O.W.; Gutiérrez, M.M.; Ferrero, A.A.; Band, B.F. Essential Oils Nanoformulations for Stored-Product Pest ControlCharacterization and Biological Properties. Chemosphere 2014, 100, 130-138. [CrossRef] [PubMed]

12. Boeke, S.; Baumgart, I.; van Loon, J.; van Huis, A.; Dicke, M.; Kossou, D. Toxicity and Repellence of African Plants Traditionally Used for the Protection of Stored Cowpea against Callosobruchus Maculatus. J. Stored Prod. Res. 2003, 40, 423-438. [CrossRef]

13. Abdelgaleil, S.A.M.; Mohamed, M.I.E.; Shawir, M.S.; Abou-Taleb, H.K. Chemical Composition, Insecticidal and Biochemical Effects of Essential Oils of Different Plant Species from Northern Egypt on the Rice Weevil, Sitophilus oryzae L. J. Pest Sci. 2015, 89, 219-229. [CrossRef]

14. González, J.O.W.; Laumann, R.A.; da Silveira, S.; Moraes, M.C.B.; Borges, M.; Ferrero, A.A. Lethal and Sublethal Effects of Four Essential Oils on the Egg Parasitoids Trissolcus Basalis. Chemosphere 2013, 92, 608-615. [CrossRef]

15. Regnault-Roger, C.; Vincent, C.; Arnason, J.T. Essential Oils in Insect Control: Low-Risk Products in a High-Stakes World. Annu. Rev. Entomol. 2012, 57, 405-424. [CrossRef]

16. Mario, M.B.; Astuti, L.P.; Hsu, J.-L.; Kafle, L. Fumigant Activity of Four Plant Powders against Cowpea Weevil, Callosobruchus Maculatus (Fabricius) (Coleoptera: Chrysomelidae) in Stored Adzuki Bean. Legum. Res.-Int. J. 2021, 1, 1-6. [CrossRef]

17. Guaouguaou, F.-E.; Bebaha, M.A.A.; Taghzouti, K.; Bouyahya, A.; Bakri, Y.; Dakka, N.; Es-Safi, N.E. Cytotoxicological Investigation of the Essential Oil and the Extracts of Cotula Cinerea and Salvia Verbenaca from Morocco. Biomed. Res. Int. 2018, 2018, 7163961. [CrossRef]

18. Chlif, N.; Ed-Dra, A.; Diouri, M.; El Messaoudi, N.; Zekkori, B.; Filali, F.R.; Bentayeb, A. Chemical Composition, Antibacterial and Antioxidant Activities of Essential Oils Extracted from Dry and Fresh Brocchia cinerea (Vis.). Biodivers. J. Biol. Divers. 2021, 22, 1741-1749. [CrossRef]

19. Djellouli, M.; Benmehdi, H.; Mammeri, S.; Moussaoui, A.; Ziane, L.; Hamidi, N. Chemical Constituents in the Essential Oil of the Endemic Plant Cotula Cinerea (Del.) from the Southwest of Algeria. Asian Pac. J. Trop. Biomed. 2015, 5, 870-873. [CrossRef]

20. Kasrati, A.; Jamali, C.A.; Bekkouche, K.; Wohlmuth, H.; Leach, D.; Abbad, A. Comparative Evaluation of Antioxidant and Insecticidal Properties of Essential Oils from Five Moroccan Aromatic Herbs. J. Food Sci. Technol. 2014, 52, 2312-2319. [CrossRef]

21. Larbi, B.A.M.; Naima, B.; Elsharkawy, E.; Neghmouche, N.S. Phytochemical Characterization, In-Vitro Cytotoxic and Antibacterial Activity of Cotula Cinerea (Delile) Vis Essential Oil. J. Nat. Remedies 2018, 18, 107-112. [CrossRef] 
22. Ghouti, D.; Lazouni, H.A.; Moussaoui, A.; Sari, D.C. Chemical Profile, in Vitro Antibacterial and Antioxidant Activities of Juniperus phoenicea L. and Cotula Cinerea (Del.) Essential Oils from Southwestern Algeria. Phytothérapie 2018, 16, S74-S83. [CrossRef]

23. Boussoula, E.; Ghanmi, M.; Satrani, B.; Alaoui, M.B.; Rhafouri, R.; Farah, A.; Amusant, N.; Chaouch, A. Chemical Quality, Antibacterial and Antifungal Activities of Cotula Cinerea Essential Oil from South Morocco. Environ. Sci. 2016, 12, $209-216$.

24. Atef, C.; Boualem, M.; Cherif, M.; Youcef, H.; Azzedine, C. Chemical Composition and Antimicrobial Activity of Essential Oils in Xerophytic Plant Cotula Cinerea Del (Asteraceae) during Two Stages of Development: Flowering and Fruiting. J. Appl. Pharm. Sci. 2015, 5, 029-034. [CrossRef]

25. Benahmed, F.; Nadjat, D. The Effect of Cotula Cinerea Essantial Oil on Spore Germination, Mycelial Growth and on Sporulation of Phytopathogenic Fungi: Aspergillus Niger. Appl. Biol. Sahar. Areas ABSA 2017, 1, 23-29.

26. El Bouzidi, L.; Abbad, A.; Fattarsi, K.; Hassani, L.; Leach, D.; Markouk, M.; Legendre, L.; Bekkouche, K. Chemical Composition and Anticandidal Properties of the Essential Oil Isolated from Aerial parts of Cotula Cinerea: A Rare and Threatened Medicinal Plant in Morocco. Nat. Prod. Commun. 2011, 6, 1491-1494. [CrossRef]

27. Reddy, D.N.; Al-Rajab, A.J. Chemical Composition, Antibacterial and Antifungal Activities of Ruta graveolens L. Volatile Oils. Cogent Chem. 2016, 2, 1220055. [CrossRef]

28. Darwish, R.S.; Hammoda, H.M.; Ghareeb, D.A.; Abdelhamid, A.S.; El Naggar, E.M.B.; Harraz, F.M.; Shawky, E. Efficacy-Directed Discrimination of the Essential Oils of Three Juniperus Species Based on their in-Vitro Antimicrobial and Anti-Inflammatory Activities. J. Ethnopharmacol. 2020, 259, 112971. [CrossRef]

29. Tsiri, D.; Graikou, K.; Poblocka-Olech, L.; Krauze-Baranowska, M.; Spyropoulos, C.; Chinou, I. Chemosystematic Value of the Essential Oil Composition of Thuja species Cultivated in Poland-Antimicrobial Activity. Molecules 2009, 14, $4707-4715$. [CrossRef]

30. Setzer, W. Antimicrobial Activity of Artemisia Douglasiana Leaf Essential Oil. Fitoterapia 2004, 75, 192-200. [CrossRef]

31. Pitarokili, D.; Tzakou, O.; Kalamarakis, A. Activity of the Essential Oil of Salvia pomifera L. ssp. Calyclna (Sm.) Hayek against Soil Borne Pathogens. J. Essent. Oil Res. 2002, 14, 72-75. [CrossRef]

32. Casiglia, S.; Bruno, M.; Senatore, F.; Rosselli, S. Chemical Composition of Essential Oils of Anthemis Secundiramea Biv. Subsp. Secundiramea (Asteraceae) Collected Wild in Sicily and their Activity on Micro-Organisms Affecting Historical Art Craft. Nat. Prod. Res. 2016, 33, 970-979. [CrossRef] [PubMed]

33. Alvarez-Castellanos, P.P.; Bishop, C.D.; Pascual-Villalobos, M.J. Antifungal Activity of the Essential Oil of Flowerheads of Garland Chrysanthemum (Chrysanthemum Coronarium) against Agricultural Pathogens. Phytochemistry 2001, 57, 99-102. [CrossRef]

34. Viljoen, A.; van Vuuren, S.; Ernst, E.; Klepser, M.; Demirci, B.; Başer, H.; Van Wyk, B.-E. Osmitopsis Asteriscoides (Asteraceae)-the Antimicrobial Activity and Essential Oil Composition of a Cape-Dutch Remedy. J. Ethnopharmacol. 2003, 88, 137-143. [CrossRef]

35. Carson, C.F.; Riley, T. V Antimicrobial Activity of the Major Components of the Essential Oil of Melaleuca Alternifolia. J. Appl. Bacteriol. 1995, 78, 264-269. [CrossRef] [PubMed]

36. Masry, S.H.D.; Taha, T.H.; Botros, W.A.; Mahfouz, H.; Al-Kahtani, S.N.; Ansari, M.J.; Hafez, E.E. Antimicrobial Activity of Camphor Tree Silver Nano-Particles against Foulbrood Diseases and Finding Out new Strain of Serratia Marcescens as a Secondary Infection on Honeybee Larvae. Saudi J. Biol. Sci. 2021, 28, 2067-2075. [CrossRef]

37. Shukla, R.; Singh, P.; Prakash, B.; Dubey, N. Antifungal, Aflatoxin Inhibition and Antioxidant Activity of Callistemon Lanceolatus (Sm.) Sweet Essential Oil and Its Major Component 1,8-Cineole against Fungal Isolates from Chickpea Seeds. Food Control 2012, 25, 27-33. [CrossRef]

38. Wagner, L.S.; Sequin, C.J.; Foti, N.; Campos-Soldini, M.P. Insecticidal, Fungicidal, Phytotoxic Activity and Chemical Composition of Lavandula Dentata Essential Oil. Biocatal. Agric. Biotechnol. 2021, 35, 102092. [CrossRef]

39. Dorman, H.J.D.; Deans, S.G. Antimicrobial Agents from Plants: Antibacterial Activity of Plant Volatile Oils. J. Appl. Microbiol. 2000, 88, 308-316. [CrossRef]

40. Xiang, F.; Bai, J.; Tan, X.; Chen, T.; Yang, W.; He, F. Antimicrobial Activities and Mechanism of the Essential Oil from Artemisia Argyi Levl. et Van. var. Argyi cv. Qiai. Ind. Crop. Prod. 2018, 125, 582-587. [CrossRef]

41. Tariq, S.; Wani, S.; Rasool, W.; Shafi, K.; Bhat, M.A.; Prabhakar, A.; Shalla, A.H.; Rather, M.A. A Comprehensive Review of the Antibacterial, Antifungal and Antiviral Potential of Essential Oils and Their Chemical Constituents against Drug-Resistant Microbial Pathogens. Microb. Pathog. 2019, 134, 103580. [CrossRef] [PubMed]

42. McDonald, L.L.; Guy, R.H.; Speirs, R.D. Preliminary Evaluation of New Candidate Materials as Toxicants, Repellents, and Attractants against Stored-Product Insects; US Agricultural Research Service: Washington, DC, USA, 1970.

43. Krzyżowski, M.; Baran, B.; Łozowski, B.; Francikowski, J. The Effect of Rosmarinus Officinalis Essential Oil Fumigation on Biochemical, Behavioral, and Physiological Parameters of Callosobruchus Maculatus. Insects 2020, 11, 344. [CrossRef] [PubMed]

44. Blancafort Alias, S.; Cuevas-Lara, C.; Martínez-Velilla, N.; Zambom-Ferraresi, F.; Soto, M.E.; Tavassoli, N.; Mathieu, C.; Heras Muxella, E.; Garibaldi, P.; Anglada, M.; et al. A Multi-Domain Group-Based Intervention to Promote Physical Activity, Healthy Nutrition, and Psychological Wellbeing in Older People with Losses in Intrinsic Capacity: AMICOPE Development Study. Int. J. Environ. Res. Public Health 2021, 18, 5979. [CrossRef]

45. Kherroubi, M.; Zerrouk, I.Z.; Rahmoune, B.; Ala, S.; Zaidat, E. Evaluation of the Potential Insecticide Activity of Three Plants Essential Oil against the Chickpea Seeds Beetles, Callosobruchus Maculatus. An. Univ. Oradea Fasc. Biol. 2021, 28 , 97-102. 
46. Matos, L.F.; Barbosa, D.R.E.S.; Lima, E.D.C.; Dutra, K.D.A.; Navarro, D.M.D.A.F.; Alves, J.L.R.; Silva, G.N. Chemical Composition and Insecticidal Effect of Essential Oils from Illicium Verum and Eugenia Caryophyllus on Callosobruchus Maculatus in Cowpea. Ind. Crop. Prod. 2020, 145, 112088. [CrossRef]

47. Jumbo, L.O.V.; Haddi, K.; Faroni, L.R.D.; Heleno, F.; Pinto, F.G.; Oliveira, E.E. Toxicity to, Oviposition and Population Growth Impairments of Callosobruchus Maculatus Exposed to Clove and Cinnamon Essential Oils. PLoS ONE 2018, 13, e0207618. [CrossRef]

48. Moura, E.D.S.; Faroni, L.R.D.A.; Zanuncio, J.C.; Heleno, F.F.; Prates, L.H.F. Insecticidal Activity of Vanillosmopsis Arborea Essential Oil and of Its Major Constituent $\alpha$-Bisabolol against Callosobruchus Maculatus (Coleoptera: Chrysomelidae). Sci. Rep. 2019, 9, 3723. [CrossRef]

49. Alves, M.D.S.; Campos, I.M.; Brito, D.D.M.C.D.; Cardoso, C.M.; Pontes, E.G.; de Souza, M.A.A. Efficacy of Lemongrass Essential Oil and Citral in Controlling Callosobruchus Maculatus (Coleoptera: Chrysomelidae), a Post-Harvest Cowpea Insect Pest. Crop Prot. 2019, 119, 191-196. [CrossRef]

50. Balouiri, M.; Bouhdid, S.; Harki, E.H.; Sadiki, M.; Ouedrhiri, W.; Ibnsouda, S.K. Antifungal Activity of Bacillus Spp. Isolated from Calotropis Procera Ait. Rhizosphere against Candida Albicans. Asian J. Pharm. Clin. Res. 2015, 8, $213-217$.

51. El Barnossi, A.; Moussaid, F.; Housseini, A.I. Antifungal Activity of Bacillussp. Gn-A11-18Isolated from Decomposing Solid Green Household Waste in Water and Soil against Candida Albicans and Aspergillus Niger. E3S Web Conf. 2020, $150,02003$. [CrossRef]

52. Elegbede, J.A.; Lateef, A.; Azeez, M.A.; Asafa, T.B.; Yekeen, T.A.; Oladipo, I.C.; Hakeem, A.S.; Beukes, L.S.; Gueguim-Kana, E.B. Silver-Gold alloy Nanoparticles Biofabricated by Fungal Xylanases Exhibited Potent Biomedical and Catalytic Activities. Biotechnol. Prog. 2019, 35, e2829. [CrossRef] [PubMed]

53. Balouiri, M.; Sadiki, M.; Ibnsouda, S.K. Methods for in Vitro Evaluating Antimicrobial Activity: A Review. J. Pharm. Anal. 2015, 6, 71-79. [CrossRef] [PubMed]

54. Chebaibi, A.; Marouf, Z.; Rhazi-Filali, F.; Fahim, M.; Ed-Dra, A. Evaluation of Antimicrobial Activity of Essential Oils from Seven Moroccan Medicinal Plants; US Department of Agriculture: Washington, DC, USA, 2016; Volume 14, pp. 355-362.

55. Eloff, J.N. A Sensitive and Quick Microplate Method to Determine the Minimal Inhibitory Concentration of Plant Extracts for Bacteria. Planta Med. 1998, 64, 711-713. [CrossRef] [PubMed]

56. Dutra, K.D.A.; de Oliveira, J.V.; Navarro, D.M.D.A.F.; Barbosa, D.R.E.S.; Santos, J.P.O. Control of Callosobruchus Maculatus (FABR.) (Coleoptera: Chrysomelidae: Bruchinae) in Vigna Unguiculata (L.) WALP. with Essential Oils from Four Citrus spp. Plants. J. Stored Prod. Res. 2016, 68, 25-32. [CrossRef]

57. Abbott, W.S. A Method of Computing the Effectiveness of an Insecticide. J. Econ. Entomol. 1925, 18, 265-267. [CrossRef]

58. Zandi-Sohani, N.; Hojjati, M.; Carbonell-Barrachina, A.Á. Insecticidal and Repellent Activities of the Essential Oil of Callistemon Citrinus (Myrtaceae) against Callosobruchus Maculatus (F.) (Coleoptera: Bruchidae). Neotrop. Entomol. 2012, 42, 89-94. [CrossRef]

59. Hewlett, P.S. Probit Analysis: D.J. Finney, 1971, 3rd ed.; Cambridge University Press: Cambridge, UK, 1972. 